Article

\title{
Analyzing the Relationship between Animal Diversity and the Remote Sensing Vegetation Parameters: The Case of Xinjiang, China
}

\author{
Jinhui Wu ${ }^{1,2, \dagger}$, Haoxin Li ${ }^{1,3,+}$, Huawei Wan ${ }^{1, *}$, Yongcai Wang ${ }^{1}$, Chenxi Sun ${ }^{1}$ and Hongmin Zhou 4 \\ 1 Satellite Environmental Application Center of Ministry of Ecology and Environment, Beijing 100094, China; \\ jwu@mail.cgs.gov.cn (J.W.); haoxin_194@163.com (H.L.); kbqinfang@163.com (Y.W.); \\ mailsunchenxi@126.com (C.S.) \\ 2 China Institute of Geo-Environment Monitoring, China Geological Survey, Beijing 100081, China \\ 3 School of Ecology and Environment, Inner Mongolia University, Hohhot 010020, China \\ 4 Beijing Engineering Research Center for Global Land Remote Sensing Products, State Key Laboratory of \\ Remote Sensing Science, Faculty of Geographical Science, Beijing Normal University, Beijing 100875, China; \\ zhouhm@bnu.edu.cn \\ * Correspondence: livelyhw@163.com \\ + Co-first author, these authors contributed equally to this work.
}

\section{check for} updates

Citation: Wu, J.; Li, H.; Wan, H.; Wang, Y.; Sun, C.; Zhou, H. Analyzing the Relationship between Animal Diversity and the Remote Sensing Vegetation Parameters: The Case of Xinjiang, China. Sustainability 2021, 13, 9897. https://doi.org/10.3390/ su13179897

Academic Editors: Carlos Antonio Da Silva Junior and Paulo Eduardo Teodoro

Received: 3 June 2021

Accepted: 16 August 2021

Published: 3 September 2021

Publisher's Note: MDPI stays neutral with regard to jurisdictional claims in published maps and institutional affiliations.

Copyright: (c) 2021 by the authors. Licensee MDPI, Basel, Switzerland. This article is an open access article distributed under the terms and conditions of the Creative Commons Attribution (CC BY) license (https:// creativecommons.org/licenses/by/ $4.0 /)$.

\begin{abstract}
An explicit analysis of the impact for the richness of species of the vegetation phenological characteristics calculated from various remote sensing data is critical and essential for biodiversity conversion and restoration. This study collected long-term the Normalized Difference Vegetation In$\operatorname{dex}(\mathrm{NDVI})$, the Leaf Area Index (LAI), the Fraction of Absorbed Photosynthetically Active Radiation (FAPAR), and the Fractional Vegetation Cover (FVC), and calculated the six vegetation phenological characteristic parameters: the mean of the growing season, the mean of the mature season, the mean of the withered season, the annual difference value, the annual cumulative value, and the annual standard deviation in the Xinjiang Uygur Autonomous Region. The relationships between the vegetation phenological characteristics and the species richness of birds and mammals were analyzed in spatial distribution. The main findings include: (1) The correlation between bird diversity and vegetation factors is greater than that of mammals. (2) For remote sensing data, FAPAR is the most important vegetation parameter for both birds and mammals. (3) For vegetation phenological characteristics, the annual cumulative value of the LAI is the most crucial vegetation phenological parameter for influencing bird diversity distribution, and the annual difference value of the NDVI is the most significant driving factor for mammal diversity distribution.
\end{abstract}

Keywords: biodiversity; species richness; birds; mammals; vegetation phenological characteristic; remote sensing

\section{Introduction}

Biodiversity refers to the ecological complex formed by organisms and their environment and the integration of various ecological processes related to it [1-3], which provides the fundamental guarantee for the sustainable development of human beings, and is also an important indicator of ecosystem health [4-7]. Animal species diversity is the most intuitive manifestation of biodiversity on a spatial scale, as it not only represents the richness and change of species in a habitat, but it also reflects the complex relationship between organisms and the environment [8-10]. The large-scale spatial distribution pattern of animal species richness is affected by a variety of environmental factors [11-14], and vegetation phenology characteristics is a critical one among them $[15,16]$. However, to our knowledge there is few definitive method to quantitatively describe the relationship between vegetation phenology characteristics and animal species richness on a large scale [17]. 
Remote sensing technology has become a powerful tool for the estimation of the trend of phenological phases over large areas, owing to its ability to conduct large-scale and longterm observations [18-20]. Ground observations and the remote sensing data both indicated that the spring phenology of plants has significantly advanced during the past decades [21]. Correspondingly, the phenology of numerous animals and its distributions have greatly changed [22]. One main drawback of remote sensing phenology research is that the remote sensing vegetation parameters that have been mostly studied the are the Normalized Difference Vegetation Index (NDVI) and the Enhanced Vegetation Index (EVI) [23-25]. With the development of remote sensing technology, a series of remote sensing vegetation parameters, such as the Fraction of Absorbed Photosynthetically Active Radiation (FAPAR), the Leaf Area Index (LAI), and the Fractional Vegetation Cover (FVC), which can reflect the characteristics of the vegetation canopy structure, have been proposed [26-28]. Compared with the NDVI and EVI, these parameters can further reflect the habitat information for species [29,30], and long-time series quantitative remote sensing datasets based on these remote sensing vegetation parameters can provide an important opportunity to analyze the spatial distribution pattern of animal species richness caused by vegetation phenology changes on a large scale [31,32]. Nonetheless, the explicit analysis of the relationship between the animal species richness and the different vegetation phenology parameters extracted with remote sensing data is almost absent from the literature.

In this study, we compared the influences of remote sensing vegetation phenology parameters on the distribution of animal diversity in Xinjiang Uygur Autonomous Region (hereinafter referred to as "Xinjiang"), which covers nearly one-sixth of the territory of China with three key regions of biodiversity [33-39]. Four remote sensing vegetation parameters were selected: NDVI, LAI, FAPAR, and FVC, which are highly accurate and are widely used. They were used to calculate and generate six types of phenological characteristic parameters of the vegetation, including the mean value in the growing season, the mean value in the mature season, the mean value in the withered season, the annual difference value, the annual cumulative value, and the annual standard deviation. In this study, animal species richness was analyzed including bird species richness and mammal species richness. Overall, this study had three specific objectives: (1) to compare the effects of vegetation on bird and mammal spatial distribution, (2) to evaluate the performance of remote sensing vegetation parameters on animal diversity distribution, and (3) to analyze the impact of vegetation phenological parameters on bird and mammal species richness.

\section{Study Area}

Xinjiang is located between $73^{\circ} 40-96^{\circ} 18 \mathrm{E}$ and $34^{\circ} 25-48^{\circ} 10 \mathrm{~N}$. It is the hinterland of the Eurasian continent, with a total area of approximately 1.66 million $\mathrm{km}^{2}$ (Figure 1). The terrain of Xinjiang is covered by mountains and basins, and the climate is temperate continental, with great differences in precipitation between the north and south. Northern Xinjiang is in the middle temperate zone, affected by the westerly belt, with more precipitation, and the annual average precipitation of Kanas Lake is more than $1000 \mathrm{~mm}[40,41]$. Southern Xinjiang is in the warm temperate zone, with less precipitation, and the annual average precipitation of Turpan is less than $20 \mathrm{~mm}$. The statistical results show that the existing cultivated land in Xinjiang is about $4.12 \times 104 \mathrm{~km}^{2}$, the available grassland is about $48.82 \times 104 \mathrm{~km}^{2}$, forest land is about $6.76 \times 104 \mathrm{~km}^{2}$, natural desert is about $43.03 \times 104 \mathrm{~km}^{2}$, oasis is about $13.4 \mathrm{~km}^{2}$, and the total area of the water area is $0.55 \times 104 \mathrm{~km}^{2}$. The rich and diverse ecological environment and unique geographical conditions provide the sufficient prerequisites for the survival of species in different habitats. 


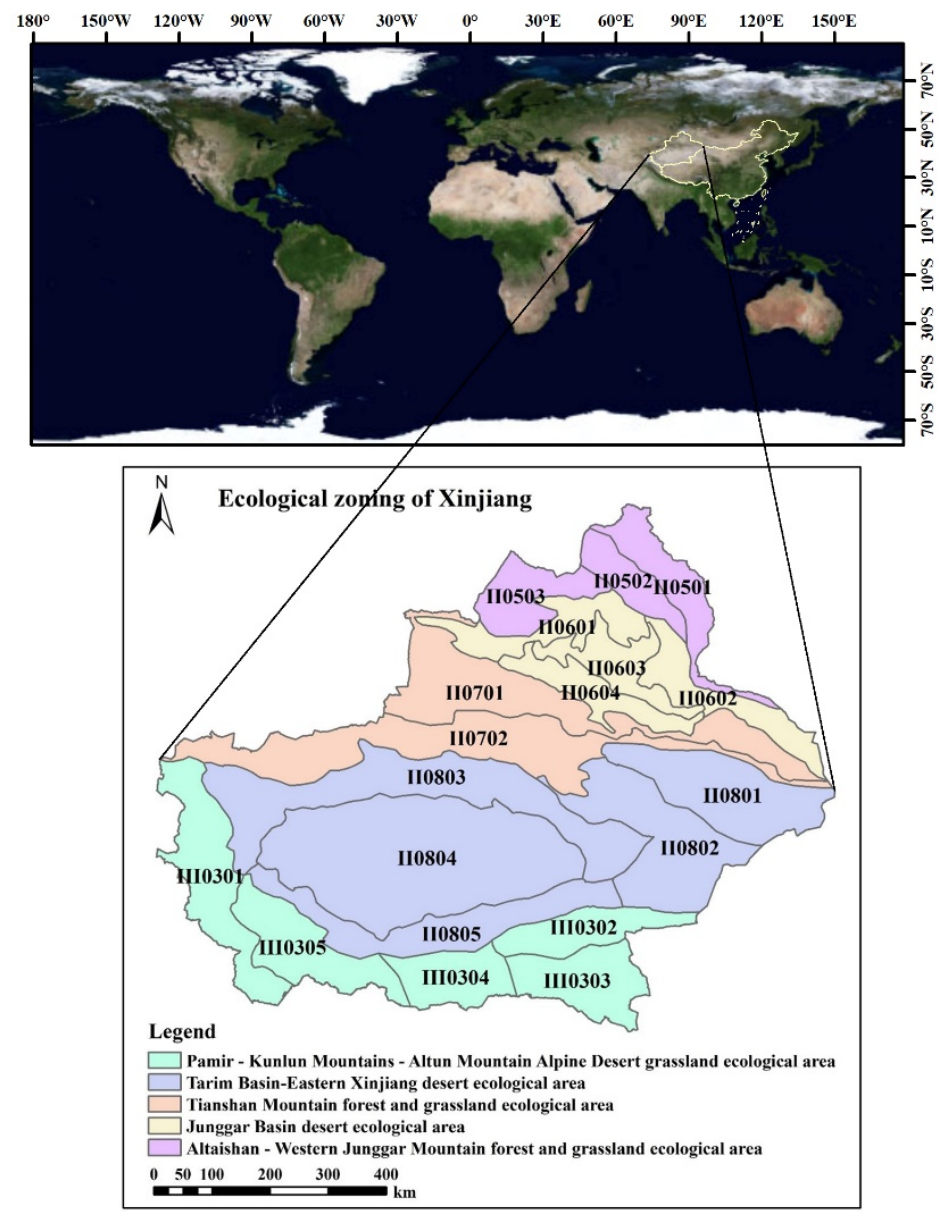

Figure 1. Location and Ecological Zoning of Xinjiang Uygur Autonomous Region.

\section{Methodology}

\subsection{Data Sources}

\subsubsection{Species Richness Data}

The species distribution data of bird and mammal were provided by the Institute of Aerospace Information Innovation, Chinese Academy of Sciences. The animal species richness data used in this study includes bird species richness and mammal species richness. The dataset is based on the spatial distribution information of the species recorded in the "Xinjiang bird list" [42] and the "Xinjiang mammal (Mammalia) list" [43]. The number of species within a $10 \times 10 \mathrm{~km}$ grid was counted to generate the raster data [44]. The whole of Xinjiang was divided into $10 \times 10 \mathrm{~km}$ grids by ArcGIS 10.8, and the number of bird and mammal species in each grid was calculated and further projected into the WGS84 coordinate system [44]. Each cell net contains information such as central coordinate, species number, family number and so on.

\subsubsection{Remote Sensing Data}

The LAI refers to the ratio of the total leaf area to land area per unit land area, which is an important parameter for characterizing the vegetation canopy structure [45]. This study used Global LAnd Surface Satellite (GLASS) LAI, which is produced in the State Key Laboratory of Remote Sensing Science, Beijing Normal University (Beijing, China) (Table 1). The time span was from 2001 to 2010, the temporal resolution was constructed every 8 days, and the spatial resolution was $1 \times 1 \mathrm{~km}$. This dataset was generated by inversion with a generalized regression neural network and showed distinct advantages over the other LAI products in terms of time-series continuity and spatial integrity, as well as a higher accuracy in woodland and arable land [46-48]. 
FAPAR refers to the proportion of photosynthetically available radiation absorbed by vegetation in the photosynthetically available radiation reaching the top of the vegetation canopy, which is a basic physiological variable describing the structure of vegetation, and it is related to the matter and energy exchange process [49]. The spatial resolution and time resolution of the GLASS FAPAR products were consistent with the GLASS LAI products. Compared with other FAPAR products, the GLASS FAPAR product effectively avoids various difficulties, such as soil albedo, which is not easily accessible on a regional scale. Further, this dataset has a high temporal and spatial continuity in the central and high latitudes of the Northern Hemisphere [50-52].

The FVC refers to the vertical projection area of green vegetation on the ground as a percentage of the total area of the statistical area, and this is used to characterize the extent of the regional vegetation coverage [53]. This research used GLASS FVC products. The time span was from 2001 to 2010 , the spatial resolution was $500 \times 500 \mathrm{~m}$, and the time resolution was 8 days. The accuracy of the GLASS FVC products in the crop vegetation coverage areas was higher than other FVC products [54-56].

The NDVI is the ratio of the difference between the near-infrared band and the red-light band to the sum of the two. It comprehensively characterizes the vegetation growth trend, vegetation coverage, and nutritional status and can reflect the plant canopy background influence $[57,58]$. This research used the MOD13A2 NDVI C6 product, with a time span from 2001 to 2010 , a spatial resolution of $1 \times 1 \mathrm{~km}$, and a time resolution of 16 days. The $\mathrm{C} 6$ version of the dataset improves the sensitivity of the product to vegetation on the basis of existing indicators and further eliminates the influence of factors such as high observation coverage, low viewing angle, cloud and cloud shadows, and aerosol concentration on data accuracy [59-61].

The original format of the remote sensing data mentioned above is HDF5. They were converted into the TIF grid format and resampled to $10 \times 10 \mathrm{~km}$ resolution by cubic convolution.

Table 1. Dataset information.

\begin{tabular}{|c|c|c|c|c|c|c|}
\hline Data Type & Data Name & Data Sources & $\begin{array}{c}\text { Time } \\
\text { Resolution (d) }\end{array}$ & $\begin{array}{l}\text { Spatial Resolution } \\
(\mathbf{k m})\end{array}$ & Time Span & Data Type \\
\hline $\begin{array}{l}\text { Species richness } \\
\text { data }\end{array}$ & $\begin{array}{l}\text { Species richness of } \\
\text { birds /mammals }\end{array}$ & $\begin{array}{c}\text { Literature } \\
\text { query statistics }\end{array}$ & $* *$ & $10 \mathrm{~km}$ & 2001-2010 & Grid \\
\hline \multirow{4}{*}{$\begin{array}{l}\text { Remote sensing } \\
\text { vegetation } \\
\text { parameter data }\end{array}$} & LAI & GLASS LAI & $8 \mathrm{~d}$ & $1 \mathrm{~km}$ & $2001-2010$ & Grid \\
\hline & FAPAR & GLASS FAPAR & $8 \mathrm{~d}$ & $1 \mathrm{~km}$ & 2001-2010 & Grid \\
\hline & FVC & GLASS FVC & $8 \mathrm{~d}$ & $0.5 \mathrm{~km}$ & $2001-2010$ & Grid \\
\hline & NDVI & $\begin{array}{c}\text { MOD13A2 } \\
\text { NDVI C6 }\end{array}$ & $16 \mathrm{~d}$ & $1 \mathrm{~km}$ & 2001-2010 & Grid \\
\hline $\begin{array}{l}\text { Ecological } \\
\text { function } \\
\text { zoning data }\end{array}$ & $\begin{array}{l}\text { Ecological function } \\
\text { zoning }\end{array}$ & $\begin{array}{c}\text { China } \\
\text { ecological } \\
\text { function } \\
\text { regionalization } \\
\text { database }\end{array}$ & ** & $* *$ & $* *$ & Vector \\
\hline
\end{tabular}

Note: ${ }^{* *}$ indicates that this item is not involved.

\subsubsection{Ecological Function Zoning Data}

In this study, the ecological function zoning data used were obtained from the EcoEnvironment Research Center of the Chinese Academy of Sciences. This dataset integrates the evaluation data of China's ecological environmental problems, ecosystem sensitivity, and the importance of ecosystem service functions. It uses a spatial overlay, a correlation analysis, and the expert integration method, while the other methods divide the national ecological function areas from top to bottom, among which Xinjiang is divided into 19 ecological function sub-regions. For the geographical location and name number of each subregion, please refer to Appendix A Table A1. 


\subsection{Research Method}

\subsubsection{Bivariate Spatial Autocorrelation Analysis}

The bivariate local autocorrelation (Moran's I) module in the GeoDa spatial analysis model was used in this study to explore the correlation between bird and mammal species richness and the spatial distribution of vegetation factors in Xinjiang. The bivariate local spatial autocorrelation can reflect the clustering relationship of two variables in a certain space. The reference distribution was generated by a random sequence used in the significance test. The results generated were Moran's I scatter diagram and a LISA (Local indicators of Spatial association) cluster diagram [62]. Global Moran's I value of the two variables determines the intensity and direction of the spatial correlation between the two variables, and this can measure the degree of convergence or how discrete the two variables are at the global level [63]. The LISA clustering graph provides information about spatial clustering, the location of outliers, and spatial correlation types, which can be divided into four types: "high-high", "low-low", "high-low", and "low-high". This study used the ecological function division as the basic statistical analysis unit. It should be noted that because the relationship between birds, mammals, and vegetation factors was explored overall, only the NDVI was selected to characterize the spatial distribution of vegetation in Xinjiang.

\subsubsection{Dynamic Threshold Method of Vegetation Phenology}

To avoid the influence of regional spatial differentiation [64-66], this study divided Xinjiang into 19 subregions (Table A1) based on the data of the ecological function division and divided the vegetation phenological nodes in each subregion as well. The annual average time series change curve of the NDVI in different ecological subregions was obtained. Referring to the improved dynamic threshold method of vegetation phenological characteristics [67,68] (Table 2), the entire year growth process of vegetation was divided into three stages: "growing season, mature season, and withered season." Because Xinjiang contains a large area of desert, the Gobi Desert, and glaciers, there is often little vegetation coverage in these areas, and the annual vegetation change is very fuzzy [69-71]. Therefore, the ecological subregions with a NDVI less than 0.12 were not divided by phenological characteristics.

Table 2. Vegetation growth and development period division.

\begin{tabular}{ccc}
\hline Developmental Period & \multicolumn{1}{c}{ Definition } & Symbol \\
\hline Growing season & $\begin{array}{l}\text { It starts from the time when the time series curve } \\
\text { grows to } 20 \% \text { of the amplitude and ends at the } \\
\text { time when it grows to } 80 \% \text {. Indicates the period } \\
\text { of vegetation growth and development. }\end{array}$ & SOS-EOS \\
Mature season & $\begin{array}{l}\text { It starts from the time when the time series curve } \\
\text { grows to } 80 \% \text { of the amplitude and ends when it } \\
\text { drops to } 80 \% \text { of the amplitude. Indicates the } \\
\text { period of the maturing of the vegetation. }\end{array}$ & EOS-SOW \\
Withered season & $\begin{array}{l}\text { It starts from the time when the time series curve } \\
\text { drops to } 80 \% \text { of the amplitude, it ends when the } \\
\text { time drops to } 20 \% \text { of the amplitude. Indicates } \\
\text { the period of the withering of the vegetation. }\end{array}$ & \\
\hline & SOW-EOW
\end{tabular}

SOS (Start of season): The vegetation growing season begins; EOS (End of season): The vegetation growing season end. SOW (Start of Withered): The vegetation Withered season begins; EOW (End of Withered): The vegetation withered season end.

(1) Mean value of vegetation growth season, maturity season, and withered season:

$$
\operatorname{VPR}_{(X i)}=\frac{\sum_{o=1}^{n} V_{(X n)}}{n}
$$


$V P R_{(X i)}$ is the average value of the LAI, NDVI, FAPAR, and FVC at different growth and development stages in the $i$ year; $X$ is either the growing season, mature season, or withered season; $n$ is the amount of data in which the remote sensing vegetation characterizes the parameters at different developmental stages; and $V_{X n}$ is the remote sensing vegetation parameter values on the $n$th day of the different development periods.

(2) Vegetation annual difference value:

$$
V R R_{(X i)}=V P M A X_{(X i)}-V P M I N_{(X i)}
$$

$V R R_{(X i)}$ is the annual difference in the LAI, NDVI, FAPAR, and FVC in the $i$ year; $X$ is the remote sensing vegetation parameter; $V P M A X_{(X i)}$ is the maximum value of the $X$ parameter in the $i$ year; and $V P M I N_{(X i)}$ is the minimum value of the $X$ parameter in the $i$ year.

(3) Vegetation annual cumulative value

$$
V C R_{(X i)}=\sum_{o=1}^{n} V_{(X n i)}
$$

$V C R_{(X i)}$ is the annual cumulative value of the LAI, NDVI, FAPAR, and FVC in the $i$ year; $X$ is the remote sensing vegetation parameter; and $V_{(X n i)}$ is the remote sensing vegetation parameter value on the nth day of the $i$ year.

(4) Vegetation annual standard deviation

$$
V S R_{(X i)}=\sqrt{\frac{\sum_{o=1}^{n}\left(V_{(X n i)}-\mu_{(X i)}\right)^{2}}{n}}
$$

$V S R_{(X)}$ is the annual standard deviation of the LAI, NDVI, FAPAR, and FVC in the $i$ year; $V_{(X n i)}$ is the remote sensing vegetation parameter value on the nth day of the $i$ year; $\mu_{(X i)}$ is the average value of the remote sensing vegetation parameter $X$ in $i$ year; $n$ is the data volume of remote sensing vegetation parameters in year $i$; and $X$ is the remote sensing vegetation parameters.

After calculating the annual vegetation phenological parameters, the mean values of the 10-year vegetation phenological characteristic parameters were obtained through the mean synthesis, as shown in Table 3.

Table 3. Long-term series of vegetation phenological characteristic parameters and their definitions.

\begin{tabular}{cc}
\hline Vegetation Parameter Index & Definitions \\
\hline$V P R_{(X \text { bin })}$ & Growing season value of remote sensing vegetation parameter $\mathrm{X}$ \\
$V P R_{(X \text { peak })}$ & Mature season value of remote sensing vegetation parameter $\mathrm{X}$ \\
$V P R_{(X e n d)}$ & Withered season value of remote sensing vegetation parameter $\mathrm{X}$ \\
$V R R_{(\mathrm{X})}$ & Annual difference value of remote sensing vegetation parameter $\mathrm{X}$ \\
$V C R_{(\mathrm{X})}$ & Annual cumulative value of remote sensing vegetation \\
& parameter $\mathrm{X}$ \\
$V S R_{(\mathrm{X})}$ & Annual standard deviation value of remote sensing vegetation \\
& parameter $\mathrm{X}$ \\
\hline
\end{tabular}

\subsubsection{GeoDetector Method}

Based on the factor detector of the GeoDetector method, this study analyzed the relationship between the vegetation phenological characteristic parameters generated by the different quantitative remote sensing products and the species richness of the birds and mammals. The GeoDetector method is a statistical method used to detect the spatial heterogeneity of a variable of interest and to reveal the underlying driving forces [72,73]. The method is composed of four modules: a risk detector, a factor detector, 
an ecological detector, and an interaction detector. The factor detector reflects the influence of vegetation phenological characteristic parameters on species richness by calculating the $q$ value (the influence of each vegetation characteristic parameter on species richness) and the $p$ value (whether it passes the significance test level, that is, an explanatory power) $[73,74]$. The factor detector is expressed as follows:

$$
q=1-\frac{\sum_{h=1}^{L} N_{h} \sigma_{h}^{2}}{N \sigma^{2}}
$$

$h=1, \ldots \ldots, L$ is the stratification of the dependent variable $Y$ or single factor $X$; $N_{h}$ and $N$ are the number of units in layer $h$ and the whole area, respectively; and $\sigma_{h}^{2}$ and $\sigma^{2}$ are the variances of the $Y$ value in layer $h$ and the entire area, respectively.

Each ecological function subregion was divided into a $5 \times 5 \mathrm{~km}$ grid, and 700 points were selected from the grid to explore the impact of the vegetation phenology on the spatial distribution of the animal species richness.

\section{Results}

\subsection{Analysis of the Spatial Pattern Relationship between Species Richness and Vegetation Factors}

The high value areas of mammal species richness are mainly distributed in the Altai Mountains in the north of Xinjiang, Tianshan Mountains in the middle, and the foot of the Kunlun Mountains in the south. Meanwhile, the low-value areas are mainly distributed in the Tarim Basin, Turpan Basin, and Jungar Basin in the middle (Figure 2), and the distribution of bird species richness is divided by the Tarim River and the Yarkant River Basin. The bird species richness in northern Xinjiang was higher than that in southern Xinjiang, while in the Zhunger region and the foot of the southern slope of Tianshan Mountain it was lower than that in the other surrounding areas.
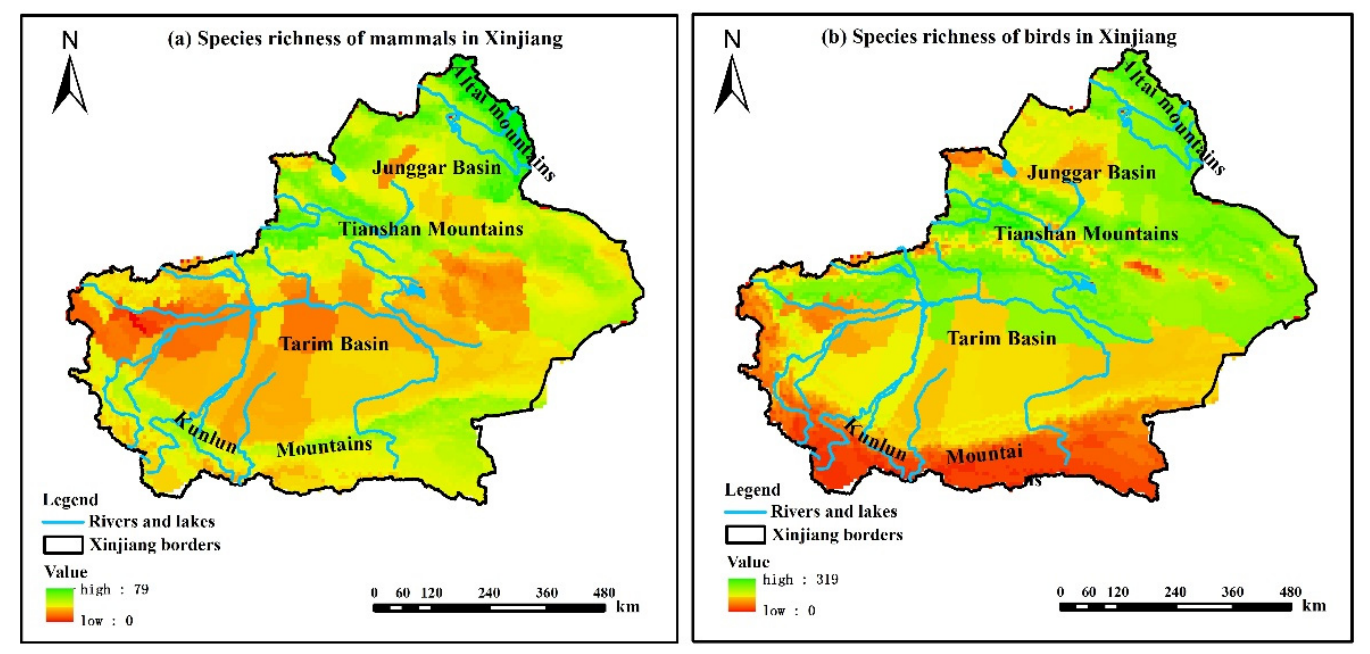

Figure 2. Spatial distribution of bird and mammal species in Xinjiang. (a) Species richness of mammals in Xinjiang; (b) Species richness of birds in Xinjiang.

Moran's I scatter diagram of the bivariate local autocorrelation is shown in Figure 3. With the number of permutations of the random sequence set to 999 times, the $p$ values of the bivariate autocorrelation results of the birds and mammals with the NDVI were less than 0.05, indicating that the results pass the significance test. According to Moran's I scatter plot, Moran's I index of birds and mammals with the NDVI were all greater than 0 , showing a strong positive correlation distribution trend in general. Further, Moran's I of birds (0.534) > Moran's I (0.229) for mammals indicates that, in terms of spatial relationship, the correlation between the bird species richness and vegetation factors was greater than the correlation between the mammal species richness and vegetation factors. In addition, Moran's I scatter diagram divided the whole into four quadrants, where the first quadrant 
represented the "high-high" aggregation of the spatial distribution of species richness and the NDVI, the second quadrant represented the "low-high" dispersion, and the third quadrant represented the "low-low" aggregation, and the fourth quadrant represented the "high-low" dispersion. In the study area, there were far more ecological function subregions proportional to NDVI (aggregation) than inversely proportional (discrete) ecological function subregions. With $95 \%$ confidence as the standard, the bivariate local autocorrelation LISA cluster map shows (Figure 4) that for birds, the areas where bird species were in abundance and the NDVI showed a "high-high" distribution were mainly concentrated in northern Xinjiang. The four subregions were II0501, II0502, II0601, and II0701. The areas of "low-low" distribution were concentrated in the four subregions of III0302, III0303, III0304, and III0305 in southern of Xinjiang. The four subregions were II0501, II0502, II0601, and II0701. The areas with a "low-low" distribution were concentrated in the four subregions of III0302, III0303, III0304, and III0305 in southern Xinjiang. For mammals, the species richness and the NDVI showed a "high-high" distribution in the subregions II0502 and II0601, and a "low-low" distribution in subregions II0802, II0804, and II0805.
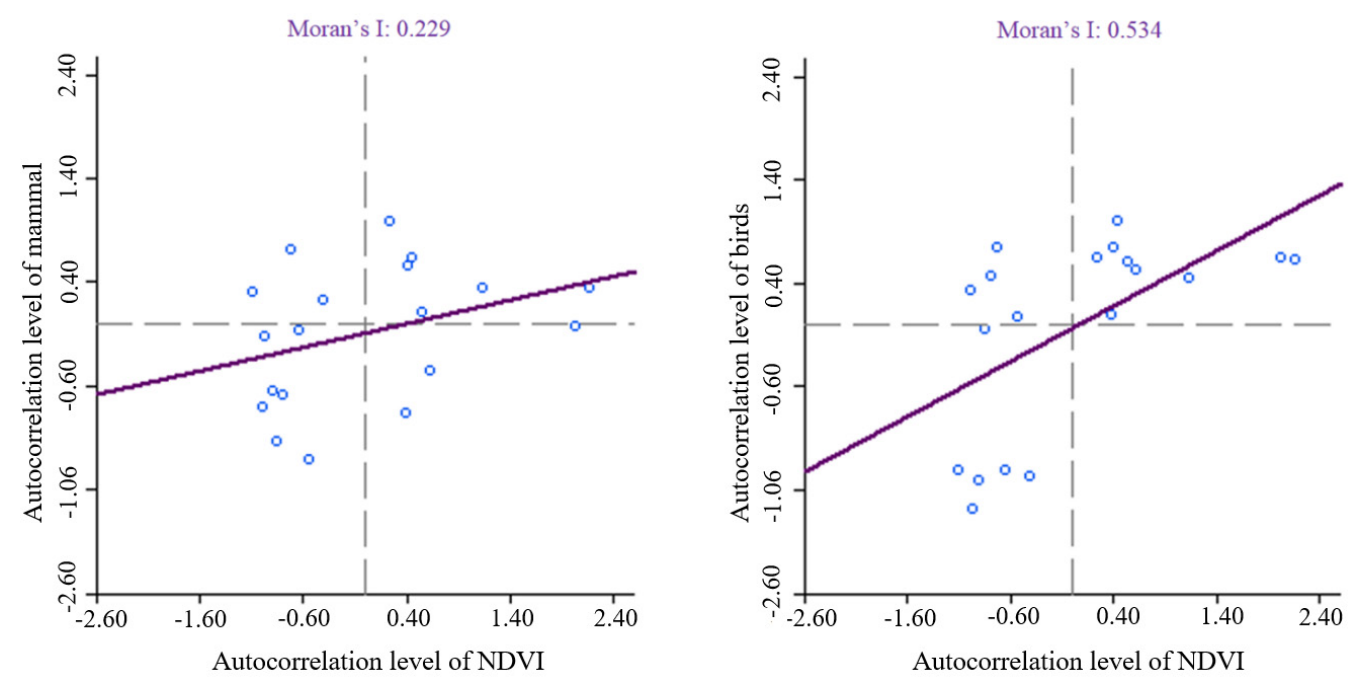

Figure 3. Moran's I scatter plot of bird and mammal species richness and vegetation factors.
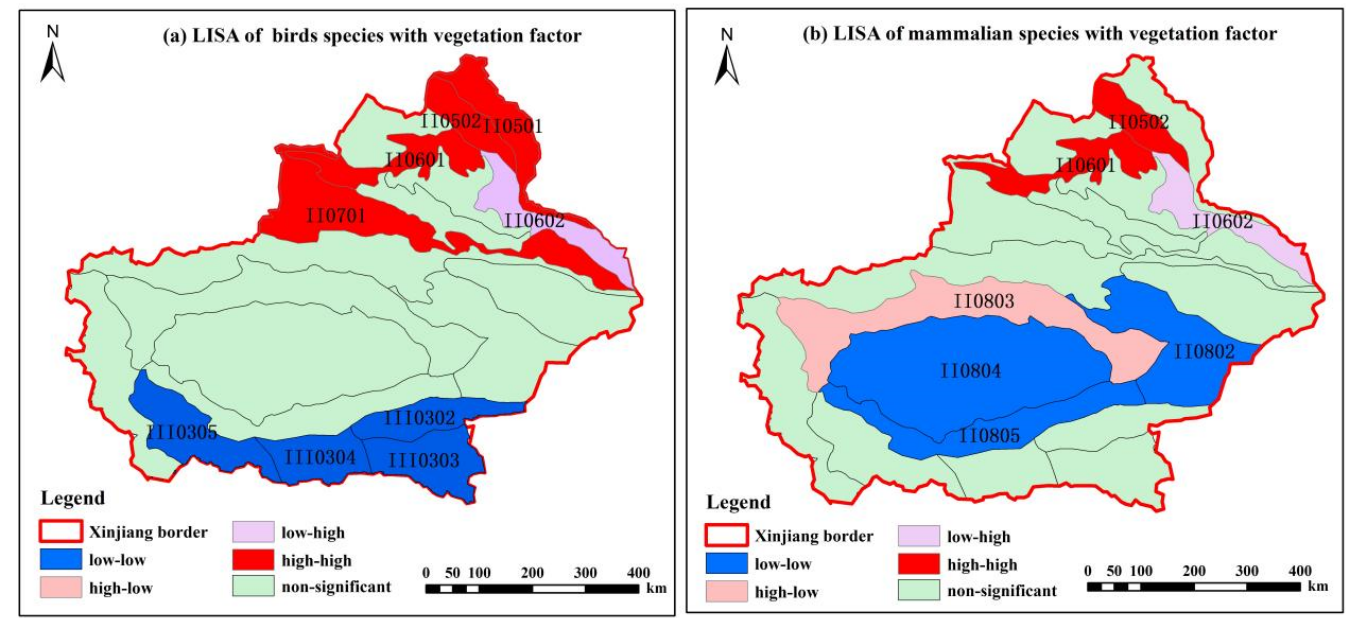

Figure 4. LISA cluster map of bird and mammal species richness and vegetation factors. Note: See Table A1 for the number and name of each partition.

\subsection{Analysis of Remote Sensing Vegetation Parameters and Vegetation Phenological Characteristics}

The yearly time-series change curve for each ecological subregion is shown in Figure 5. The vegetation change in each ecological subregion showed a trend of increasing first and 
then decreasing, with the largest annual variation range in zone II0501, with a range of 0.420 , followed by zone II0604, with a range of 0.415 .

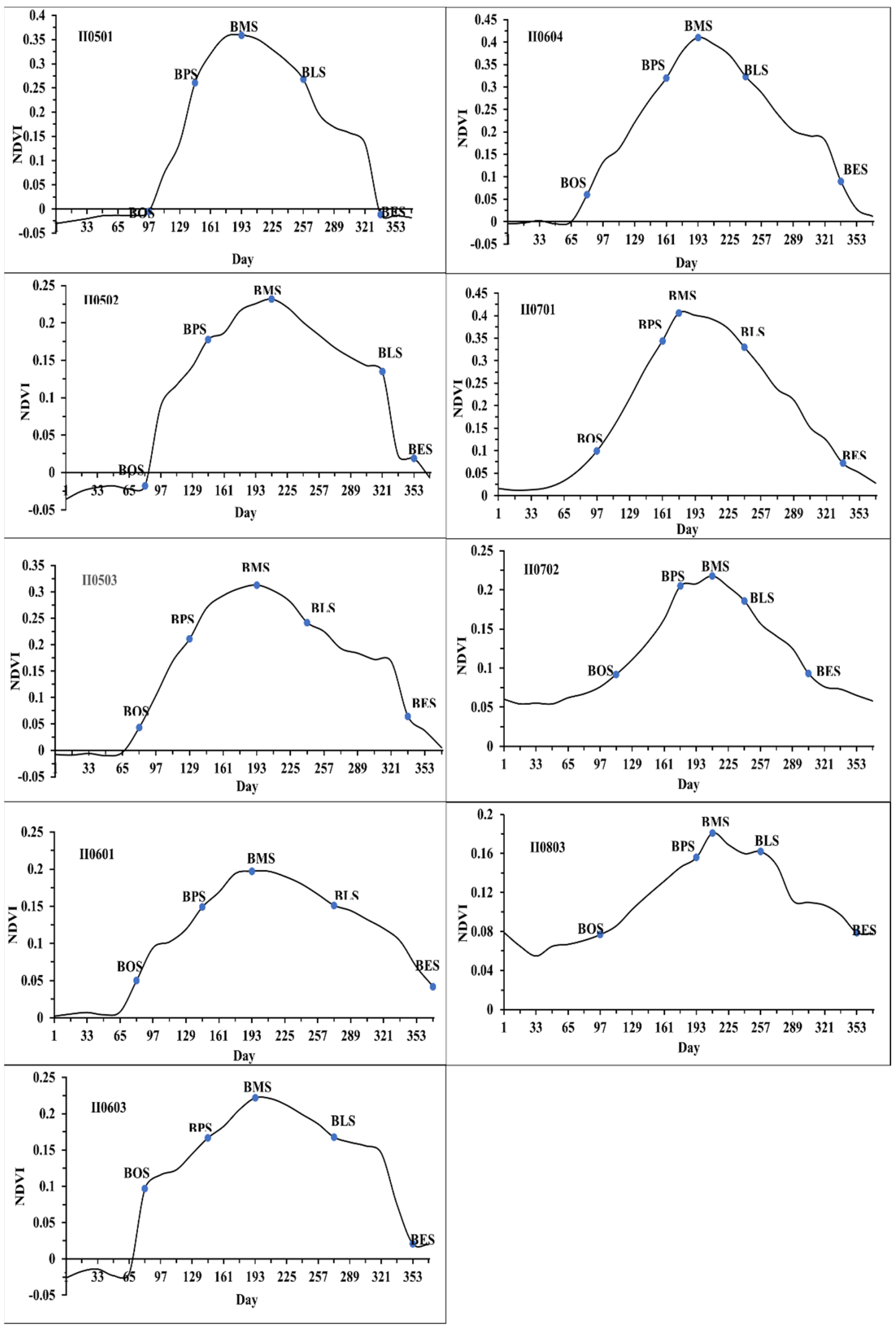

Figure 5. Long-term NDVI time series change curve in different ecological subregions (For the number of each ecological subregion and the name of the corresponding ecological subregion, see Table A1). 
Comparing the phenological change curve of each ecological subregion, the results showed that the beginning of the growing season and the end of the withered season varied in the different ecological subregions. The beginning of the growing season in II0502, II0503, II0601, II0603, and II0604 were earlier than those in II0501, II0701, II0702, and II0803, while the end of the withered season was the opposite. Overall, the duration of the vegetation growth season in Xinjiang was 48-96 days, the duration of the mature season was 64-96 days, and, the duration of the withered season was 64-112 days. The duration of the growth season was shorter than that of the mature and withered seasons. In addition, the duration of the withered season varied in different ecological zones when compared to the mature and growing seasons.

Overall, the spatial distribution of vegetation in Xinjiang is characterized by obvious geopolitical features. Vegetation is mainly distributed in the Altay Mountains in the north, northern, and southern slopes of the Tianshan Mountains in the middle, oases around the Tarim Basin, and foot of the Kunlun Mountains in the south. Comparing the characteristic parameters of the growth season, the mature season, and the withered season, it can be observed that the vegetation changes mainly occurred in the western part of the Tianshan Mountains, the foot of the Altay Mountains, and the woodlands and grasslands of the oasis around the Tarim Basin. The spatial distribution trend of the annual variation range and the annual standard deviation of vegetation parameters was consistent. This indicates that the vegetation change in Xinjiang was stable in the growth cycle and the seasonal change characteristics of vegetation were evident. The annual cumulative value of vegetation phenological characteristic parameters represents the comprehensive situation of each vegetation parameter. Through comparison, the spatial distribution trend of the four vegetation parameters was relatively consistent, but there were still differences in some areas. For example, the annual cumulative value of the NDVI showed a higher value on the northern slopes of the Altai Mountains, but the other three vegetation parameters in this area were relatively low.

\subsection{Analysis of the Relationship between Vegetation Phenological Characteristic Parameters and Species Richness}

Overall, the driving force (q value) of the vegetation phenological characteristics generated by the four quantitative remote sensing datasets to the spatial distribution of mammal species richness was higher than that of birds (Table 4). The mean value in the withered season of FVC and the other factors of the two species (birds and mammals) passed the significance test level $(p<0.05)$. From the perspective of the vegetation parameters, among all the vegetation parameters, the six vegetation phenological characteristic parameters based on the FAPAR had the highest driving force for species richness for the two classes of animals. Compared with bird species, the difference in the driving forces of the phenological characteristic parameters based on various remote sensing vegetation parameters on mammal species richness were more evident. In addition to the FAPAR-based vegetation parameters, the driving forces of the remaining vegetation parameters on mammal species richness from high to low were LAI-based, NDVI-based, and FVC-based vegetation parameters. Specific to the different vegetation phenological characteristic parameters, the annual standard deviation of the NDVI had the largest driving effect on the richness of mammal species (q value), and the annual cumulative value of LAI had the largest driving effect on the richness of birds (q value). Moreover, it can be observed from the factor detection results of the mean values of the vegetation growth season, the vegetation maturity season, the vegetation withering season with the species richness of birds and mammals, that for mammals, the q values of the four types of vegetation parameters FAPAR, FVC, LAI, and NDVI were $0.019,0.021,0.063$, and 0.045 , respectively. For birds, the range of variation in the q values was $0.004,0.020,0.031$, and 0.029 , respectively. This shows that the vegetation conditions at different growth and development periods had little effect on the species richness of birds and mammals. 
Table 4. The detection results of bird and mammal species richness and vegetation phenological characteristic parameters.

\begin{tabular}{|c|c|c|c|c|c|c|c|}
\hline $\begin{array}{l}\text { Vegetation } \\
\text { Parameters }\end{array}$ & $\begin{array}{c}\text { Vegetation } \\
\text { Phenological } \\
\text { Characteristic } \\
\text { Parameters }\end{array}$ & $\begin{array}{l}\text { Bird } q \\
\text { Value }\end{array}$ & $\begin{array}{c}\text { Mammal } \mathbf{q} \\
\text { Value }\end{array}$ & $\begin{array}{l}\text { Vegetation } \\
\text { Parameters }\end{array}$ & $\begin{array}{c}\text { Vegetation } \\
\text { Phenological } \\
\text { Characteristic } \\
\text { Parameters }\end{array}$ & $\begin{array}{l}\text { Bird q } \\
\text { Value }\end{array}$ & $\begin{array}{c}\text { Mammal q } \\
\text { Value }\end{array}$ \\
\hline \multirow{6}{*}{ NDVI } & $V P R_{(N D V I, b i n)}$ & 0.059 * & 0.139 * & \multirow{6}{*}{ FVC } & $V P R_{(F V C, b i n)}$ & 0.064 * & 0.141 * \\
\hline & $V P R_{(N D V I, \text { end })}$ & $0.076^{*}$ & 0.097 * & & $V P R_{(F V C, \text { end })}$ & 0.053 & 0.100 \\
\hline & $V P R_{(N D V I, p e a k)}$ & $0.088^{*}$ & $0.142 *$ & & $V P R_{(F V C, p e a k)}$ & $0.073 *$ & 0.120 * \\
\hline & $V R R_{(N D V I)}$ & 0.037 * & 0.208 * & & $V R R_{(F V C)}$ & $0.086^{*}$ & 0.154 * \\
\hline & $V S R_{(N D V I)}$ & $0.035 *$ & $0.243 *$ & & $V S R_{(F V C)}$ & $0.078 *$ & 0.136 * \\
\hline & $V C R_{(N D V I)}$ & $0.042 *$ & $0.046^{*}$ & & $V C R_{(F V C)}$ & 0.077 * & $0.148 *$ \\
\hline \multirow{6}{*}{ FAPAR } & $V P R_{(F A P A R, b i n)}$ & 0.101 * & 0.169 * & \multirow{6}{*}{ LAI } & $V P R_{(L A I, b i n)}$ & $0.086^{*}$ & 0.179 * \\
\hline & $V P R_{(F A P A R, \text { end })}$ & $0.105 *$ & 0.188 * & & $V P R_{(L A I, \text { end })}$ & $0.067 *$ & $0.122 *$ \\
\hline & $V P R_{(F A P A R, p e a k)}$ & 0.103 * & 0.174 * & & $V P R_{(L A I, p e a k)}$ & 0.098 * & $0.185 *$ \\
\hline & $V R R_{(F A P A R)}$ & 0.074 * & 0.198 * & & $V R R_{(F V C)}$ & $0.092 *$ & 0.158 * \\
\hline & $V S R_{(F A P A R)}$ & 0.070 * & 0.189 * & & $V S R_{(L A I)}$ & 0.090 * & 0.164 * \\
\hline & $V C R_{(F A P A R)}$ & 0.111 * & 0.199 * & & $V C R_{(L A I)}$ & $0.115^{*}$ & 0.178 * \\
\hline
\end{tabular}

Note: ${ }^{*}$ means passing the randomness test, that is, $p<0.05$.

\section{Discussion}

\subsection{Spatial Pattern Relationship between Species Richness and Vegetation Factors}

In this study, the high-value areas of mammal species richness were mainly concentrated in the valleys between the mountains and the high value areas of bird species richness were mainly concentrated in the river-intensive areas. This indicates that the spatial distribution of mammal species was greatly affected by altitude factors, as the elevation would lead to a decrease in temperature, thus affecting the species habitat, and the spatial distribution of bird species was mainly affected by water sources, which is the same as the research results of $\mathrm{Wu}$ [75] on a global scale. This study found that the areas where bird species richness and vegetation showed a "high-high" aggregation pattern were mainly concentrated in the II0501, II0502, II0601, and II0701 subregions in northern Xinjiang, the mammal species richness and vegetation showed a "high-high" aggregation pattern mainly concentrated in subregions II0502 and II0601. This is because there are large areas of mountain forests and grasslands in the Altay Mountains and Tianshan Mountains in the north of Xinjiang. Further, the Erqis, Yili, and Wulungu rivers, which are formed by the melting of alpine snow, provide sufficient water for the survival of the species, and the suitable habitat conditions attract many species. There are large desert areas such as the Gobi, Taklimakan, and Lop Nur, in the subregions II0802, II0804, and II0805 in central Xinjiang, the climate is dry and hot, and the vegetation distribution is rare, because the ability of birds for activity is far greater than mammals [76,77], mammals are more restricted by the environmental conditions in the above mentioned areas, leading to the "low-low" aggregation mode of the mammals and vegetation. In every subregion in Xinjiang southern, owing to the influence of the Kunlun Mountains (high altitude, cold climate, and large amount of alpine snow) the conditions are not conducive to the growth of vegetation; at the same time, the flight height of birds is greatly affected by the elevation [78,79]. Therefore, the "low-low" aggregation model of the bird species and vegetation was observed in this region.

\subsection{Analysis of Vegetation Parameters and the Phenological Characteristics of Remote Sensing}

In this study, we found that the largest annual change in vegetation growth in the Xinjiang region was zone II0501, with a range of 0.420 , followed by zone II0604, with a range of 0.415 . In these two subregions, the entire Altay Mountain range and the Middle Tianshan Mountain range are distributed there, the normal ecological environment was good, the vegetation grew vigorously, and the vegetation development cycle changed significantly in 1 year. The results showed that the start and end times of the vegetation 
growth season and withered season in different ecological subregions varied. For example, the start time of the growth season in II0502, II0503, II0601, II0603, and II0604 were earlier than those of II0501, II0701, and II0702, and II0803. However, the end time of the withered season was the opposite, which is mainly affected by latitude and elevation [80,81]. The higher the latitude and the higher the elevation, the later the vegetation enters the growing season and the earlier the end of the withered season. Conversely, the lower the latitude and the lower the elevation, the earlier the vegetation enters the growing season and the later the end of the withered season.

\subsection{Analysis of the Relationship between Vegetation Phenological Characteristic Parameters and Species Richness}

The results showed that the driving force of the four vegetation parameters on mammal species richness was higher than that of birds, which is mainly due to two reasons. First, birds have a stronger range and ability of activity than mammals and are less affected by topographical variability. Second, mammals are often much larger in size than birds, and they need more energy than birds. Among the four vegetation parameters, the FAPAR had the highest driving force on bird and mammal species richness, indicating that the amount of solar radiation absorbed by vegetation has a significant impact on animal species diversity, which is consistent with the results of Long and Kerr et al. [82,83]. From the perspective of vegetation phenological characteristic parameters, the annual cumulative value of the LAI had the greatest impact on the spatial distribution of bird species richness, while the annual standard deviation of the NDVI had the greatest impact on the spatial distribution of mammal species richness, which is mainly due to the different demands of birds and mammals on vegetation factors. The dependence of birds on vegetation factors is mainly due to the requirements of the habitat conditions (such as nesting) [84,85]. Compared with other vegetation phenological characteristic parameters, the annual cumulative value of the LAI can better reflect the three-dimensional structure information of plant canopy leaves, and it can comprehensively characterize the growth of plants. Therefore, the annual cumulative value of the LAI is the vegetation phenological characteristic parameter that has the greatest impact on the spatial distribution of birds; mammals have a more comprehensive dependence on vegetation factors [86-88], the more stable the vegetation conditions, the smaller the interference on mammals. The annual standard deviation of the NDVI can better reflect the change and stability of the vegetation factors. Therefore, the annual standard deviation of the NDVI is the vegetation phenological characteristic parameter that has the greatest impact on the spatial distribution of mammals. The effect of vegetation in the different growth and development periods on the richness of birds and mammals was relatively small. This result is since, in the study area, although the vegetation growth progress in different geographical regions was different due to different topographical conditions, climatic conditions, and other factors, the overall change trend over one entire year was still consistent. Although wild birds and mammals have a strong migration ability, there is little difference in the developmental stage of vegetation in the range of their survival ability. In addition, most of the animal species distributed in Xinjiang belong to fixed habitat animals; after long-term evolution, they have fully adapted to the living environment of the habitat. In essence, the spatial distribution of animals is the result of their active or passive adaptation to environmental changes $[89,90]$. Therefore, the effect of seasonal vegetation replacement on bird and mammal species richness was relatively small.

\subsection{Limitations and Future Research}

This study analyzed the relationship between the vegetation phenological characteristic parameters and the species richness of birds and mammals in Xinjiang. However, there are two known limitations: First, vegetation phenological parameters in this study were all obtained from the quantitative remote sensing data. At present, there is still a lack of mechanistic analysis from the perspectives of ecology, verification, and comparison of field observation experiments. Second, this study analyzed the diversity of two class 
animal, while various species own different characteristics in detail. To better explain the effects of the different vegetation parameters and the various vegetation phenological parameters on the distribution of animal diversity, future studies will consider the integrated observation experiment of space-sky-earth and will analyze more specific animal classes or singles species.

\section{Conclusions}

In this study, we took Xinjiang as the study are, and collected the spatialized species richness and vegetation parameters. We used a bivariate local autocorrelation (Moran's I) to analyze the spatial distribution relationship between the abundance of birds and mammals and the vegetation factors. Using the GeoDetector method, the relationship between the vegetation phenological characters and the species richness of birds and mammals in Xinjiang were obtained. To discuss the difference of different vegetation parameters from remote sensing data, four vegetation parameters and six phenological metrics were selected and were calculated. This study improves our understanding of vegetation phenology's impact on the spatial distribution of animal species richness and provides a scientific basis for biodiversity conservation and restoration

According to the analysis results, the following conclusions are drawn:

(1) The bivariate local autocorrelation Moran's I scatter points show that the spatial relationship between bird and mammal species richness and the vegetation factors showed a strong positive correlation trend, with clustering characteristics, and Moran's I of birds (0.534) > Moran's I (0.229) of mammals. In terms of spatial distribution, the correlation between birds and vegetation factors is greater than that of mammals.

(2) The LISA cluster map showed that the spatial distribution of the abundance of bird species and vegetation factors showed a "high-high" clustering area mainly in central and northern areas of Xinjiang (II0501, II0502, II0601, and II0701 subregions). The areas with "low-low" clusters were concentrated in the southern areas of Xinjiang (III0302, III0303, III0304, and III0305 subregions). For mammals, the areas where the species richness and vegetation factors had a "high-high" clustering were mainly concentrated in northern areas of Xinjiang (II0502 and II0601 subregions). The areas with "low-low" clustering were mainly concentrated in the central areas of Xinjiang (II0802, II0804, and II0805 subregions).

(3) From the aspect of the vegetation parameters, FAPAR is the most important vegetation parameter for birds and mammals. From the aspect of the vegetation phenological characteristic parameters, the annual cumulative value of the LAI is the most important driving factor for birds, and the annual variance of the NDVI is the most important driving factor for mammals.

Author Contributions: H.L., J.W., Y.W. and C.S. performed the data curation; J.W., H.Z. and H.W. analyzed the data and contributed to the analysis of the results; H.W., J.W. and H.L. towards writing the manuscript. All authors have read and agreed to the published version of the manuscript.

Funding: This research was funded by National Natural Science Foundation of China (41801366 and 42101407), and by National Key Research and Development Program of China (2018YFC0507201).

Institutional Review Board Statement: Ethical review and approval were waived for this study, due to Our study does not involve specific animal species.

Informed Consent Statement: Informed consent was obtained from all subjects involved in the study.

Conflicts of Interest: The authors declare no conflict of interest. 


\section{Appendix A}

Table A1. Xinjiang ecological area and subregion.

\begin{tabular}{|c|c|c|}
\hline Number & Ecological Area & Ecological Subregions \\
\hline II0501 & $\begin{array}{l}\text { Altaishan-Western Junggar Mountain } \\
\text { forest and grassland ecological area }\end{array}$ & $\begin{array}{c}\text { Ecological subregion of larch forest of } \\
\text { Siberia on the southern slope of } \\
\text { altai mountain }\end{array}$ \\
\hline II0502 & $\begin{array}{l}\text { Altaishan-Western Junggar Mountain } \\
\text { forest and grassland ecological area }\end{array}$ & $\begin{array}{l}\text { Ecological subregion of Ertysi-wulungu } \\
\text { river desert steppe }\end{array}$ \\
\hline II0503 & $\begin{array}{l}\text { Altaishan-Western Junggar Mountain } \\
\text { forest and grassland ecological area }\end{array}$ & $\begin{array}{l}\text { Ecological subregion of Mountain } \\
\text { grassland in the western Junggar basin }\end{array}$ \\
\hline II0601 & Junggar Basin desert ecological area & $\begin{array}{l}\text { Desert-oasis agro-ecological subregion } \\
\text { in the western margin of Junggar basin }\end{array}$ \\
\hline II0602 & Junggar Basin desert ecological area & $\begin{array}{l}\text { Ecological subregion of shrub desert in } \\
\text { the eastern junggar basin }\end{array}$ \\
\hline II0603 & Junggar Basin desert ecological area & $\begin{array}{c}\text { Ecological subregion of Fixed and } \\
\text { semi-fixed desert in the central } \\
\text { Junggar Basin }\end{array}$ \\
\hline II0604 & Junggar Basin desert ecological area & $\begin{array}{l}\text { Agro-ecological subregion of shrub and } \\
\text { semi-shrub desert and oasis in southern } \\
\text { Junggar Basin }\end{array}$ \\
\hline II0701 & $\begin{array}{l}\text { Tianshan Mountain forest and } \\
\text { grassland ecological area }\end{array}$ & $\begin{array}{l}\text { Ecological subregion of Spruce } \\
\text { forest-grassland on the Northern Slope of } \\
\text { Tianshan Mountains }\end{array}$ \\
\hline II0702 & $\begin{array}{l}\text { Tianshan Mountain forest and } \\
\text { grassland ecological area }\end{array}$ & $\begin{array}{c}\text { Agro-ecological subregion of desert } \\
\text { steppe and oasis on the southern slope of } \\
\text { Tianshan Mountains }\end{array}$ \\
\hline II0801 & $\begin{array}{l}\text { Tarim Basin Eastern Xinjiang } \\
\text { desert ecological area }\end{array}$ & $\begin{array}{l}\text { Ecological subregion of desert oasis and } \\
\text { Agroecological in Turpan Hami Basin }\end{array}$ \\
\hline II0802 & $\begin{array}{c}\text { Tarim Basin-Eastern Xinjiang desert } \\
\text { ecological area }\end{array}$ & $\begin{array}{c}\text { Eastern Xinjiang gobi-mobile desert } \\
\text { ecological subregion }\end{array}$ \\
\hline II0803 & $\begin{array}{c}\text { Tarim Basin-Eastern Xinjiang desert } \\
\text { ecological area }\end{array}$ & $\begin{array}{c}\text { Desert-oasis agro-ecological subregion } \\
\text { in northern Tarim basin }\end{array}$ \\
\hline II0804 & $\begin{array}{c}\text { Tarim Basin-Eastern Xinjiang desert } \\
\text { ecological area }\end{array}$ & Taklimakan Desert ecological subregion \\
\hline II0805 & $\begin{array}{c}\text { Tarim Basin Eastern Xinjiang desert } \\
\text { ecological area }\end{array}$ & $\begin{array}{c}\text { Desert-oasis agro-ecological subregion } \\
\text { in southern Tarim basin }\end{array}$ \\
\hline III0301 & $\begin{array}{c}\text { Pamir-Kunlun Mountains-Altun } \\
\text { Mountain Alpine Desert grassland } \\
\text { ecological area }\end{array}$ & $\begin{array}{c}\text { Ecological subregion of alpine desert } \\
\text { steppe in the Pamir } \\
\text { Karakoram Mountains }\end{array}$ \\
\hline III0302 & $\begin{array}{c}\text { Pamir-Kunlun Mountains-Altun } \\
\text { Mountain Alpine Desert grassland } \\
\text { ecological area }\end{array}$ & $\begin{array}{l}\text { Desert ecological sub-area of } \\
\text { Altun Mountain }\end{array}$ \\
\hline III0303 & $\begin{array}{c}\text { Pamir-Kunlun Mountains-Altun } \\
\text { Mountain Alpine Desert grassland } \\
\text { ecological area }\end{array}$ & $\begin{array}{c}\text { The ecological subregion of alpine desert } \\
\text { steppe in the eastern part of } \\
\text { Kunlun mountains }\end{array}$ \\
\hline III0304 & $\begin{array}{l}\text { Pamir-Kunlun Mountains-Altun } \\
\text { Mountain Alpine Desert grassland } \\
\text { ecological area }\end{array}$ & $\begin{array}{c}\text { The ecological subregion of alpine desert } \\
\text { steppe in the middle part of } \\
\text { Kunlun mountains }\end{array}$ \\
\hline III0305 & $\begin{array}{l}\text { Pamir-Kunlun Mountains-Altun } \\
\text { Mountain Alpine Desert grassland } \\
\text { ecological area }\end{array}$ & $\begin{array}{c}\text { The ecological subregion of alpine desert } \\
\text { steppe in the west part of } \\
\text { Kunlun mountains }\end{array}$ \\
\hline
\end{tabular}




\section{References}

1. Jiang, Z.; Ma, K.; Han, X. Conservation Biology; Zhejiang Science and Technology Press: Hangzhou, China, 1997.

2. Gaston, K.J. Global patterns in biodiversity. Nature 2000, 405, 220-227. [CrossRef] [PubMed]

3. Kennedy, T.A.; Naeem, S.; Howe, K.M.; Knops, J.; Tilman, D.; Reich, P.J.N. Biodiversity as a barrier to ecological invasion. Nature 2002, 417, 636-638. [CrossRef] [PubMed]

4. Chapin, F.S., 3rd; Zavaleta, E.S.; Eviner, V.T.; Naylor, R.L.; Vitousek, P.M.; Reynolds, H.L.; Hooper, D.U.; Lavorel, S.; Sala, O.E.; Hobbie, S.E.; et al. Consequence of changing biodiversity. Nature 2000, 405, 232-242.

5. Mckinney, M.L.J.B. Urbanization, Biodiversity, and Conservation. BioScience 2002, 52, 883-890. [CrossRef]

6. Iii, F.; Zavaleta, E.S.; Eviner, V.T.; Naylor, R.L.; Vitousek, P.M.; Reynolds, H.L.; Hooper, D.U.; Lavorel, S.; Sala, O.E.; Hobbie, S.E.J.B. Consequences of changing biodiversity. Nature 1998, 48, 45-52.

7. Van Strien, A.J.; Meyling, A.W.G.; Herder, J.E.; Hollander, H.; Kalkman, V.J.; Poot, M.J.M.; Turnhout, S.; van der Hoorn, B.; van Strien-van Liempt, W.T.F.H.; van Swaay, C.A.M.; et al. Modest recovery of biodiversity in a western European country: The Living Planet Index for the Netherlands. Biol. Conserv. 2016, 200, 44-50. [CrossRef]

8. Liu, H. Response Mechanism of Species Diversity to Spatiotemporal Heterogeneity of Habitat Destruction; Nanjing Normal University: Nanjing, China, 2006.

9. Willis, K.J.; Whittaker, R.J. Species diversity-Scale matters. Science 2002, 295, 1245-1248. [CrossRef]

10. Rosenzweig, M.L. Species Diversity in Space and Time; Cambridge University Press: Cambridge, UK, 1995.

11. Durnota, B. An Abstract Object Model of an Animal's Environment. Ecol. Model. 1996, 86, 119-123. [CrossRef]

12. Tarsitano, E. Interaction Between the Environment and Animals in Urban Settings: Integrated and Participatory Planning. Environ. Manag. 2006, 38, 799-809. [CrossRef]

13. Braaker, S.; Moretti, M.; Boesch, R.; Ghazoul, J.; Obrist, M.K.; Bontadina, F. Assessing habitat connectivity for ground-dwelling animals in an urban environment. Ecol. Appl. 2014, 24, 1583-1595. [CrossRef]

14. Shugart, L.R.; Mccarthy, J.F.; Halbrook, R.S. Biological Markers of Environmental and Ecological Contamination: An Overview. Risk Anal. 1992, 12, 353-360. [CrossRef]

15. Mwendera, E.J.; Saleem, M.A.M. Vegetation Dynamics of Sloping Lands under Different Grazing Pressures in the Highlands of Ethiopia. UNISWA Res. J. Agric. Sci. Technol. 2000, 4, 44-54. [CrossRef]

16. Milanovich, J.R.; Peterman, W.E.; Barrett, K.; Hopton, M.E. Do species distribution models predict species richness in urban and natural green spaces? A case study using amphibians. Landsc. Urban Plan. 2012, 107, 409-418. [CrossRef]

17. Li, L.; Nurbay, A.; Wang, S.; Wang, Z.; Tang, Z. Hydrothermal interpretation of the distribution pattern of species richness of wild vascular plants in Xinjiang. Arid Zone Res. 2011, 28, 25-30. [CrossRef]

18. Nagendra, H.; Lucas, R.; Honrado, J.P.; Jongman, R.H.G.; Tarantino, C.; Adamo, M.; Mairota, P. Remote sensing for conservation monitoring: Assessing protected areas, habitat extent, habitat condition, species diversity, and threats. Ecol. Indic. 2013, 33, 45-59. [CrossRef]

19. Jha, C.S.; Goparaju, L.; Tripathi, A.; Gharai, B.; Singh, J.S. Forest fragmentation and its impact on species diversity: An analysis using remote sensing and GIS. Biodivers. Conserv. 2005, 14, 1681-1698. [CrossRef]

20. Mohamed, A. Spatial Modeling of Site Productivty and Plant Species Diversity Using Remote Sensing and Geographical Information System; Colorado State University: Fort Collins, CO, USA, 2011.

21. Fu, Y.H.; Piao, S.; Op de Beeck, M.; Cong, N.; Zhao, H.; Zhang, Y.; Menzel, A.; Janssens, I.A. Recent spring phenology shifts in western Central Europe based on multiscale observations. Glob. Ecol. Biogeogr. 2014, 23, 1255-1263.

22. Dunn, P.O.; Møller, A.P. Changes in breeding phenology and population size of birds. J. Anim. Ecol. 2014, 83, 729-739. [CrossRef]

23. John, R.; Chen, J.; Lu, N.; Guo, K.; Liang, C.; Wei, Y.; Noormets, A.; Ma, K.; Han, X.-G. Predicting plant diversity based on remote sensing products in the semi-arid region of Inner Mongolia. Remote Sens. Environ. 2008, 112, 2018-2032.

24. Waring, R.H.; Coops, N.C.; Fan, W.; Nightingale, J.M. MODIS enhanced vegetation index predicts tree species richness across forested ecoregions in the contiguous U.S.A. Remote Sens. Environ. 2006, 103, 218-226.

25. Krishnaswamy, J.; Bawa, K.S.; Ganeshaiah, K.N.; Kiran, M.C. Quantifying and mapping biodiversity and ecosystem services: Utility of a multi-season NDVI based Mahalanobis distance surrogate. Remote Sens. Environ. 2009, 113, 857-867. [CrossRef]

26. Viña, A.; Gitelson, A.A. New developments in the remote estimation of the fraction of absorbed photosynthetically active radiation in crops. Geophys. Res. Lett. 2005, 32, 131-149. [CrossRef]

27. Myneni, R.B.; Ramakrishna, R.; Nemani, R.; Running, S.W. Estimation of global leaf area index and absorbed par using radiative transfer models. IEEE Trans. Geosci. Remote Sens. 2002, 35, 1380-1393. [CrossRef]

28. Zeng, X.; Rao, P.; Defries, R.S.; Hansen, M.C. Interannual Variability and Decadal Trend of Global Fractional Vegetation Cover from 1982 to 2000. J. Appl. Meteorol. 2003, 42, 1525-1530. [CrossRef]

29. Myers, N.; Mittermeier, R.A.; Mittermeier, C.G.; da Fonseca, G.A.; Kent, J. Biodiversity hotspots for conservation priorities. Nature 2000, 403, 853-858. [CrossRef]

30. Wu, J.; Chen, B.; Reynolds, G.; Xie, J.; Liang, S.; O’Brien, M.J.; Hector, A. Chapter Three-Monitoring tropical forest degradation and restoration with satellite remote sensing: A test using Sabah Biodiversity Experiment. In Advances in Ecological Research; Dumbrell, A.J., Turner, E.C., Fayle, T.M., Eds.; Academic Press: Cambridge, MA, USA, 2020; Volume 62, pp. 117-146.

31. Skidmore, A.K.; Coops, N.C.; Neinavaz, E.; Ali, A.; Schaepman, M.E.; Paganini, M.; Kissling, W.D.; Vihervaara, P.; Darvishzadeh, R.; Feilhauer, H.; et al. Priority list of biodiversity metrics to observe from space. Nat. Ecol. Evol. 2021, 5, 896-906. [CrossRef] 
32. Middleton, A.D.; Kauffman, M.J.; McWhirter, D.E.; Cook, J.G.; Cook, R.C.; Nelson, A.A.; Jimenez, M.D.; Klaver, R.W. Animal migration amid shifting patterns of phenology and predation: Lessons from a Yellowstone elk herd. Ecology 2013, 94, $1245-1256$. [CrossRef]

33. Dong, W.; Cui, B.; Liu, Z.; Zhang, K. Relative effects of human activities and climate change on the river runoff in an arid basin in northwest China. Hydrol. Process. 2014, 28, 4854-4864. [CrossRef]

34. Yao, J.; Zhao, Y.; Chen, Y.; Yu, X.; Zhang, R. Multi-scale assessments of droughts: A case study in Xinjiang, China. Sci. Total Environ. 2018, 630, 444-452. [CrossRef]

35. Luo, M.; Liu, T.; Meng, F.; Duan, Y.; Bao, A.; Xing, W.; Feng, X.; De Maeyer, P.; Frankl, A. Identifying climate change impacts on water resources in Xinjiang, China. Sci. Total Environ. 2019, 676, 613-626. [CrossRef]

36. Tang, H.; Yan, L.; Zhang, X. Biodiversity conservation and a conception for a national desert park in Dzungaria Basin, Xinjiang. Biodivers. Sci. 2008, 16, 618.

37. Yuan, G. Distribution and Evaluation of Biodiversity in Xinjiang; Xinjiang Science and Technology Press: Xinjiang, China, 2012; Volume 13, pp. 231-249.

38. Chen, Y.; Zhang, H.; Li, W.; Chen, Y. Relationship between species diversity and groundwater level in the lower reaches of Tarim River in Xinjiang. Adv. Earth Sci. 2005, 2, 158-165.

39. Yuan, G.; Chen, L.; Cheng, J. Investigation and evaluation of biodiversity in Xinjiang. Environ. Prot. Xinjiang 2010, $32,1-6$.

40. Xue, Y.; Han, P.; Feng, G. Change Trend of the Precipitation and Air Temperature in Xinjiang since Recent 50 Years. Arid Zone Res. 2003, 20,49-52.

41. Chen, Y.; Xu, C.; Yang, Y.; Hao, X.; Shen, Y. Change of hydrology and water resources in Xinjiang and its response to regional climate change. Acta Geogr. Sin. 2009, 64, 1331-1341.

42. Ma, M. List of Birds in Xinjiang; Science Press: Beijing, China, 2001.

43. Abulimiti, Y. List of Mammals in Xinjiang; Data before 2010; Xinjiang Institute of Ecology and Geography; Chinese Academy of Sciences: Beijing, China, 2002.

44. Li, L.; Yin, L.; Tang, Z. Distribution pattern of species richness of wild animals and plants in Xinjiang. Study Arid Area 2011, $28,1-9$.

45. Liu, Y.; Ju, W.; Chen, J.; Zhu, G.; Xing, B.; Zhu, J.; He, M. Spatiotemporal variation characteristics of forest leaf area index in China from 2000 to 2010. Sci. Bull. 2012, 57, 1435.

46. Xiao, Z.; Liang, S.; Wang, J.; Chen, P.; Yin, X.; Zhang, L.; Song, J. Sensing, R. Use of General Regression Neural Networks for Generating the GLASS Leaf Area Index Product From Time-Series MODIS Surface Reflectance. IEEE Trans. Geosci. Remote Sens. 2013, 52, 209-223. [CrossRef]

47. Liu, Y.; Zhou, J. Comparison of MODIS, CYCLOPES and GLASS in Hanjiang River Basin. Remote Sens. Land Resour. 2018, $30,14-21$.

48. Liang, S.; Zhao, X.; Liu, S.; Yuan, W.; Cheng, X.; Xiao, Z.; Zhang, X.; Liu, Q.; Cheng, J.; Tang, H.; et al. A long-term Global LAnd Surface Satellite (GLASS) data-set for environmental studies. Int. J. Digit. Earth 2013, 6 (Suppl. S1), 5-33. [CrossRef]

49. Mccallum, I.; Wagner, W.; Schmullius, C.; Shvidenko, A.; Obersteiner, M.; Fritz, S.; Nilsson, S. Comparison of four global FAPAR datasets over Northern Eurasia for the year 2000. Remote Sens. Environ. 2010, 114, 941-949. [CrossRef]

50. Xiao, Z.; Liang, S.; Wang, T.; Jiang, B. Retrieval of Leaf Area Index (LAI) and Fraction of Absorbed Photosynthetically Active Radiation (FAPAR) from VIIRS Time-Series Data. Remote Sens. 2016, 8, 351. [CrossRef]

51. Xiao, Z.; Liang, S.; Sun, R. Evaluation of Three Long Time Series for Global Fraction of Absorbed Photosynthetically Active Radiation (FAPAR) Products. IEEE Trans. Geosci. Remote Sens. 2018, 56, 5509-5524. [CrossRef]

52. Xiao, Z.; Liang, S.; Sun, R.; Wang, J.; Jiang, B. Estimating the fraction of absorbed photosynthetically active radiation from the MODIS data based GLASS leaf area index product. Remote Sens. Environ. 2015, 171, 105-117. [CrossRef]

53. Xiao, Z.; Wang, T.; Liang, S.; Sun, R. Estimating the Fractional Vegetation Cover from GLASS Leaf Area Index Product. Remote Sens. 2016, 8, 337. [CrossRef]

54. Mu, X.; Huang, S.; Ren, H.; Yan, G.; Song, W.; Ruan, G. Validating GEOV1 Fractional Vegetation Cover Derived From CoarseResolution Remote Sensing Images Over Croplands. IEEE J. Sel. Top. Appl. Earth Obs. Remote Sens. 2014, 8, 439-446. [CrossRef]

55. Liu, D.; Jia, K.; Wei, X.; Xia, M.; Wang, B. Spatiotemporal Comparison and Validation of Three Global-Scale Fractional Vegetation Cover Products. Remote Sens. 2019, 11, 2524. [CrossRef]

56. Jia, K.; Liang, S.; Wei, X.; Yao, Y.; Yang, L.; Zhang, X.; Liu, D. Validation of Global LAnd Surface Satellite (GLASS) fractional vegetation cover product from MODIS data in an agricultural region. Remote Sens. Lett. 2018, 9, 847-856. [CrossRef]

57. Wang, Z.X.; Liu, C.; Huete, A. From AVHRR-NDVI to MODIS-EVI: Advances in vegetation index research. Acta Ecol. Sin. 2003, 23, 979-987.

58. Jing, W.; Ni, G.; Wang, X.; Jia, Y. Comparisons of normalized difference vegetation index from MODIS Terra and Aqua data in northwestern China. In Proceedings of the IEEE International Geoscience \& Remote Sensing Symposium, Boston, MA, USA, 6-11 July 2008.

59. Verbyla, D. Comparison of eMODIS and MOD/MYD13A2 NDVI products during 2012-2014 spring green-up periods in Alaska and northwest Canada. Int. J. Appl. Earth Obs. Geoinf. 2015, 36, 83-86. [CrossRef]

60. Kern, A.; Marjanović, H.; Bognár, P.; Pásztor, S.; Barcza, Z. Applications of a MODIS-adjusted NDVI3g dataset in Central Europe between 1982 and 2013. In Proceedings of the Egu General Assembly Conference, Vienna, Austria, 23-28 April 2017. 
61. Wang, G.J.; Huang, J.L.; Xiao, F.; Feng, Q.J.R.; Basin, E.I.T.Y. Comparison of AVHRR NDVI and MODIS NDVI Data Products Based on Association and Trend Analysis. Resources and Environment in the Yangtze Basin. 2018. Available online: http: / /yangtzebasin.whlib.ac.cn/EN/article/showNewArticle.do (accessed on 17 July 2021).

62. Abdi, O.; Shirvani, Z.; Buchroithner, M.F. Visualization and quantification of significant anthropogenic drivers influencing rangeland degradation trends using Landsat imagery and GIS spatial dependence models:A case study in Northeast Iran J. Geogr. Sci. 2018, 28, 1933-1952.

63. Xie, Y.; Zhang, S.; Lin, B.; Zhao, Y.; Hu, B. Spatial division of land ecological restoration in Guangxi county based on the relationship between supply and demand of ecosystem services. J. Nat. Resour. 2020, 35, 217-229.

64. Yuan, J.; Kang, M.; Liu, S.; Tian, L.; Lei, M. A study on the vegetation in the east side of Helan Mountain. Plant Ecol. 2000, 149, 119-130. [CrossRef]

65. Ren, S.; Chen, X.; An, S. Assessing plant senescence reflectance index-retrieved vegetation phenology and its spatiotemporal response to climate change in the Inner Mongolian Grassland. Int. J. Biometeorol. 2017, 61, 601-612. [CrossRef]

66. Gao, J.; Jiao, K.; Wu, S.J. Investigating the spatially heterogeneous relationships between climate factors and NDVI in China during 1982 to 2013. J. Geogr. Sci. 2019, 29, 1597-1609. [CrossRef]

67. Jnsson, P.; Eklundh, L. Geosciences. TIMESAT-A program for analyzing time-series of satellite sensor data. Comput. Geosci. 2004, 30, 833-845. [CrossRef]

68. Li, C.; Deng, F.; Zhang, J.; Wang, X.; Wei, W. Ma Qingxiao. Analysis of phenological spatial characteristics in Hubei Province Based on time series vegetation index. Resour. Environ. Yangtze River Basin 2019, 28, 1583-1589.

69. DeFries, R.S. NDVI-derived land cover classification at a global scale. Int. J. Remote Sens. 1994, 15, 3567-3586.

70. Zhang, X.; Wu, S.; Yan, X.; Chen, Z. A global classification of vegetation based on NDVI, rainfall and temperature. Int. J. Climatol. 2017, 37, 2318-2324. [CrossRef]

71. Pu, R.; Gong, P.; Tian, Y.; Miao, X.; Anderson, G.L. Using classification and NDVI differencing methods for monitoring sparse vegetation coverage: A case study of Saltcedar in Nevada, USA. Int. J. Remote Sens. 2008, 29, 3987-4011. [CrossRef]

72. Wang, J.; Xu, J. Geographical detector: Principle and Prospect. Acta Geogr. Sin. 2017, 72, 116-134.

73. Su, Y.; Li, T.; Cheng, S.; Wang, X. Spatial distribution exploration and driving factor identification for soil salinisation based on geodetector models in coastal area. Ecol. Eng. 2020, 156, 105961. [CrossRef]

74. Wei, W.; Samat, A.; Abuduwaili, J.; Ge, Y. Quantifying the influences of land surface parameters on LST variations based on GeoDetector model in Syr Darya Basin, Central Asia. J. Arid Environ. 2021, 186, 104415.

75. Wu, J.; Liang, S. Developing an Integrated Remote Sensing Based Biodiversity Index for Predicting Animal Species Richness. Remote Sens. 2018, 10, 739. [CrossRef]

76. Ding, P. Development and Current Situation of Bird Ecology in China. J. Zool. 2002, 3, 71-78.

77. Sekercioglu, C.H. Conservation Ecology: Area Trumps Mobility in Fragment Bird Extinctions. Curr. Biol. CB 2007, 17, R283-R286. [CrossRef] [PubMed]

78. Gómez, C.; Gómez-Bahamón, V.; Cárdenas-Ortíz, L.; Bayly, N.J. Distribution of Nearctic-Neotropical migratory birds along a South American elevation gradient during spring migration. Wilson J. Ornithol. 2015, 127, 72-86. [CrossRef]

79. Benson, T.J.; Brown, J.D.; Anich, N.M.; Bednarz, J.C. Habitat availability for bottomland hardwood forest birds: The importance of considering elevation. J. Field Ornithol. 2011, 82, 25-31.

80. Jeganathan, C.; Dash, J.; Atkinson, P.M. Remotely sensed trends in the phenology of northern high latitude terrestrial vegetation, controlling for land cover change and vegetation type. Remote Sens. Environ. 2014, 143, 154-170.

81. Feng, J.; Dong, X.; Xu, C.; Cha, F. Effects of sampling scale on the latitudinal distribution pattern of seed plant species diversity in Northwest Yunnan. Biodiversity 2009, 17, 266-271.

82. Long, C.; Wan, H.; Li, L.; Wang, J. Spatial Pattern and Relationship between Bird and Mammal Richness and Environmental Factors in Xinjiang. J. Remote Sens. 2019, 23, 155-165.

83. Kerr, J.T.; Southwood, T.R.E.; Cihlar, J. Remotely sensed habitat diversity predicts butterfly species richness and community similarity in Canada. Proc. Natl. Acad. Sci. USA 2001, 98, 11365-11370. [CrossRef]

84. Winter, M.; Johnson, D.H.; Shaffer, J.A. Variability in Vegetation Effects on Density and Nesting Success of Grassland Birds. J. Wildl. Manag. 2005, 69, 185-197. [CrossRef]

85. Hasui, É.; Gomes, V.S.M.; Silva, W.R. Effects of vegetation traits on habitat preferences of frugivorous birds in Atlantic rain forest. Biotropica 2007, 39, 502-509. [CrossRef]

86. Rosa, G.L. Effects of Vegetation Structure on the Habitat Use of Small Terrestrial Mammals at Camp Maxey; Texas, M.S., Stephen, F., Eds.; Austin State University: Nacogdoches, TX, USA, 2006.

87. Abdullahi, H.A. Effects of Vegetation Disturbance on Small Mammals Diversity and Distribution in Oloolua Forest, Kenya. Master's Thesis, University of Nairobi, Nairobi, Kenya, 2010.

88. Thompson, C.M.; Gese, E.M. Influence of vegetation structure on the small mammal community in a shortgrass prairie ecosystem. Acta Theriol. 2013, 58, 55-61. [CrossRef]

89. Xia, L.; Yang, Q.; Xiang, Y.; Feng, Z. Distribution Pattern and Zoogeographical Analysis of Mammals in Qilian Mountain Areas, Qinghai, China. Acta Theriol. Sin. 2006, 23, 295.

90. Hou, L.; Ma, L. Glires of Eastern Xinjiang and Their Zoogeographical Distribution. Arid Zone Res. 1998, 3, $173-191$. 